Article

\title{
Strong Religion in a Secular Society: The Case of Orthodox Reformed Schools in The Netherlands
}

\author{
John Exalto ${ }^{1, * \mathbb{D}}$ and Gerdien Bertram-Troost ${ }^{2}$ \\ 1 Department of Educational Studies, Vrije Universiteit Amsterdam, Van der Boechorststraat 7, \\ 1081 BT Amsterdam, The Netherlands \\ 2 Faculty of Religion and Theology \& Department of Educational Studies, Vrije Universiteit Amsterdam, \\ De Boelelaan 1105, 1081 HV Amsterdam, The Netherlands; g.d.bertram-troost@vu.nl \\ * Correspondence: j.exalto@vu.nl
}

Received: 14 November 2018; Accepted: 23 January 2019; Published: 28 January 2019

check for updates

\begin{abstract}
In the Netherlands, state and religious schools are equally financed by the government. Parents are free to choose a school that optimally fits their moral values as well as their idea of a good education. As a result, there is a huge variety of schools, which include those orthodox Reformed schools that form part of the so-called Bible Belt culture. We elaborate on the complex relation between this religious culture and liberal, secular society by focusing on education. Occasionally, there is severe criticism of schools based on a strong religious identity (so-called strong religious schools), especially when it comes to their allegedly inadequate contribution to citizenship education. In order to add a historical perspective and a reflection on the arguments to the debate, our central research question is: 'How can the founding and existence of orthodox Reformed schools in the Dutch liberal and secular society be explained and justified?' Starting with a historical explanation of why the orthodox Reformed founded their own schools in the 1920s, we elaborate on philosophical arguments that can justify the existence of orthodox Reformed schools in a liberal, secular society.
\end{abstract}

Keywords: strong religious schools; Dutch Bible Belt; citizenship education; religious education; liberal society; secularization

\section{Introduction}

It is now the best and worst of times for faith schools [ ... ]. These schools are seen as infringing the individual freedom of the children educated in them, undermining social cohesion by promoting ethnic and religious segregation, infringing students' autonomy, and perpetuating religious indoctrination. They are also championed as defenders of liberty and religious freedom where those who do not wish to be coerced into conformity with the values of the secular mainstream can thrive and be free from state control [1] (p. 181).

The quotation above is taken from the opening sentences of an article by Pike, reporting on his research on strong religious education. On the basis of a comparison between a Dutch and an English strong Christian school, Pike challenged those assumptions mentioned in the quotation and responded to the claim that "the real challenge for liberals lies in dealing with the strong version of cultural identity schooling" ([2], p. 85, quoted in Reference [1], p. 182). The charges made against these faith-based schools are rather serious and have important implications for both education policy and the schools themselves. Especially in the British context, where the annual Ofsted Inspection Report of 2017 [3] triggered a forceful public response to faith schools (e.g., [4]), the debates surrounding strong religious schools and their contribution to society as a whole are particularly relevant today. Equally in other countries, both inside and outside Europe, there is an ongoing discussion and, from time to time, 
even huge political and societal debate, on the purpose of strong religious schools in liberal, secular societies (e.g., [5,6]). Although the specific contexts differ, and there is great diversity among religious schools (e.g., [6]), the questions about how religious (minority) groups (can) relate to liberal society and what the role of (religious) education could or should be without upsetting wider social cohesion are similar. In this article, we contextualize the discussion by focusing on orthodox Reformed schools in the Netherlands.

Pike, in line with McDonough [7] (p. 464), defined a schooling environment based on a strong identity as one that seeks "to foster a separate education of extensive scope and duration that is meant to ensure that children adhere to a distinct ancestral identity throughout their lives". Such schools also aim "to restrict membership to individuals from a particular cultural, racial, ethnic, national or linguistic group" and "to advance a separate education affirming and reinforcing the identity of the group in question" [1] (p. 182). Pike made it clear that strong religious schools are under attack for, amongst other reasons, undermining social cohesion and infringing students' autonomy. From a liberal and secular perspective, these are core values that cannot simply be taken for granted. However, strong religious schools can also be of great importance in today's secular society, as they defend the religious freedom of minority groups. In this article, which focuses on orthodox Reformed schools in the Netherlands as an example of strong religious schools, we engage with both sides of the debate.

The Dutch school involved in Pike's study is the Jacobus Fruytier Scholengemeenschap. This is a strong religious school that only admits students (and staff) who belong to an orthodox group within Reformed Protestantism located in the Dutch 'Bible Belt'. Reformed orthodoxy must be distinguished from fundamentalism: To its adherents, religious tradition is of high authority but not changeless and static, as the interpretation of the Bible is fallible. Because of its view on society, Bible Belt culture thus has the power to change over time. Those who live in the Bible Belt participate fully in Dutch politics: They accept democracy, contribute to society, and do not attempt to impose their values on the whole of society, as some fundamentalist ideologies do. The ideal of a 'theocracy', honored by a small minority of the orthodox Reformed, is not only highly theoretical but in the last years has been abandoned by most adherents [8].

The Jacobus Fruytier Scholengemeenschap is fully financed by the Dutch government. Pike does not dwell on this fact, as he believes that "the history of the acceptance of such schooling within Dutch liberal democratic society is well known" [1] (p. 187). Yet we contend that the history of Dutch strong religious schools is not well known at all and that knowledge of this history is critical in order to understand the existence and survival of these kinds of schools in the 21st century. Thus, we begin by attending to the founding of these schools, before elaborating on the complex relationship between mainstream and Bible Belt culture by focusing on school education within this strong religious group. After detailing the historical and contextual framework, we further analyze those arguments that justify strong religious schools in general and the Reformed schools in the Netherlands in particular, as their founding and history can also be used as an argument for their existence. The arguments we discuss are mainly drawn from the field of philosophy of education. We refer to, amongst others, the work of Strike [9], who stresses the role of comprehensive life conceptions in a plural, liberal democracy, and of MacMullen [10], who maintains that, especially in the early years (primary school), a close fit between a student's home and school life is beneficial for autonomy development in the long term. MacMullen [6] also made it clear that a school's contribution to citizenship education is, although very important, not the only dimension that should be taken into account when evaluating the existence of religious schools. In our conclusion, we formulate an answer to our central research question: How can we explain and justify the founding and continued existence of strong religious schools in a liberal, secular society? Our aim is to add historical awareness and a reflection on the arguments to the debates on the existence of both orthodox Reformed schools in the Netherlands and strong religious schools more generally. 


\section{Dutch Bible Belt Culture}

The strong religious schools in the Netherlands we focus on are known as 'Reformed schools' (reformatorische scholen) and are situated in the so-called Bible Belt. The label 'Bible Belt' has a double meaning: First, it denotes, as an appropriation of the American Bible Belt, the regional concentration of orthodox Reformed Christians, located in a strip that extends from the Northeast to the Southwest of the Netherlands; second, it refers to a culture of strong Christian people, living in contrast with modern society and in various ways resisting liberal politics and ethics. Some of their characteristic moral values include a belief in God's providence over human life (and for that reason, a resistance to abortion and euthanasia); an adherence to traditional Christian norms, such as marriage between one man and one woman; and a belief in creation instead of evolution. Christians in the Bible Belt often attract attention because of their divergent behavior, which includes church attendance twice each Sunday (as part of respecting Sunday rest), women and girls wearing skirts (as an expression of the difference between man and woman), and the absence of televisions in their homes (an act of resisting the sinful 'world') [11]. In 2015, the estimated total population in the Bible Belt was around 250,000 [12] (p. 141). This amounts to some 1.65 percent of the Dutch population, a small minority when compared to the 16 percent Protestants, 25 percent Catholics and 4.8 percent Muslims [13] (p. 6, all percentages for 2015).

The Dutch Bible Belt has conservative Protestant counterparts in other Western European liberal democracies. The rise of Muslim extremism after 2001 reinforced the stigmatization of these strong religious groups, as Christian fundamentalists and some liberal politicians even referred to the Dutch Bible Belt as the 'Taliban on clogs' [14]. Such language clearly demonstrates the (perceived) chasm between these orthodox religious cultures and modern society, a clash between an orthodox or strong religious culture and a secular idea of the public sphere dominated by liberal ideas of man and the world. As members of a conservative Christian culture, those in the Bible Belt preserve conservative moral values and detach themselves from contemporary culture, labelled by them as 'godless' and 'pagan'; but, although they adhere to traditional values, they are, in contrast to Muslim immigrants, rooted in Western society. Sixteenth- and seventeenth-century Calvinism is highly influential for their way of life [7]. Thus, however much they may be stigmatized as the 'Taliban on clogs', they have demonstrated how they belong to Western society and do not use violence, but rather only habits and practices, to resist modernity.

In the early decades of the 20th century, Dutch Bible Belt culture organized itself for the first time, founding its two main organizations before the Second World War: The political party Staatkundig Gereformeerde Partij (SGP: Reformed Political Party, 1918) and the school organization Vereeniging voor Gereformeerd Schoolonderwijs (VGS: Association for Reformed Education, 1921). These institutions represented the strict Reformed communities on various levels in public life and for the first time made this segment of society more visible in the public sphere as a separate group of orthodox Christians. As a result of the comparatively low electoral threshold in the Netherlands, the SGP has been represented in the Dutch Parliament since 1921. The SGP initially presented itself as a protest party against three requirements of the state-female voting, assurance for laborers, and vaccination of schoolchildren -in a bid to resist the state's influence over the moral values of its citizens, while the party's views on gender (female voting) and the belief in God's providence above human intervention (as in the cases of assurance and vaccination) deviated from mainstream culture.

Building on this first wave of organization, after the Second World War, Bible Belt culture developed a further public profile. School founding played an important role in this, as discussion below will show. The Bible Belt in the Netherlands since the 1960s can be characterized as a reaction to the secularization of society, a resistance to the modern, liberal, and secular world. Since then, the Bible Belt has been a visible counterculture in the Dutch lowlands, notable for its divergent behavior and persistently conservative values and habits. However, the Bible Belt itself is not an unchangeable block of rigid convictions. While the religious ideology has remained the same over the years, some attitudes towards ethical issues have changed in the emancipation process that the Bible Belt culture 
went through. The present-day use of modern (social) media is a clear example of changing values, especially given that in the 1960s, television was forbidden by the church leaders. The increasing numbers of divorces since the 1990s could also be interpreted as a sign of changing ethical norms, influenced by modern, secular society [15].

\section{Establishing orthodox Reformed schools in the Netherlands}

For the continuation of Bible Belt culture, the 'Bible Belt schools' are particularly important, since these schools inculcate the values in the new generation. In the Dutch context, these schools are labelled by the legislator, as well as by the department of education and the Bible Belt adherents themselves, as 'Reformed schools'. The principal organization of orthodox Reformed education, the VGS, represented as of 1 October 2016 a total of 70,179 pupils, 177 schools for primary education, 7 schools for secondary education, a few special education schools, and one technical and vocational training school. The contribution of this Reformed education to the total of the Dutch school system is about 2.5 percent (annual report VGS 2016, http:/ / www.vgs.nl/wp-content/uploads/VGS_jaarverslag2016.pdf; pupil data by denomination from the department of education, https:/ /www.duo.nl/open_onderwijsdata/ databestanden/.) Although the values these schools promote do not fully correspond with that of present-day liberal democracy-for example, their views on marriage, (homo)sexual relationships, and the equality of different religions-they are fully funded by the state, in contrast to faith-based schools in most other West European countries [16].

The equal funding of public and faith-based schools has a long history of political and public debate, dating back to the so-called School Battle or school controversy in the first half of the 19th century, which was prompted by orthodox Catholics and Protestants dissatisfied with the existing public-school system and its moderate Protestant character. The new Constitution of 1848 was an important step in the right direction for the orthodox parties, as it guaranteed freedom of education and allowed for the founding of 'special' or faith-based schools besides the public schools. These schools had to be financed privately. As the political opposition between liberal and confessional bodies grew in the second half of the century, the School Battle also intensified. The first state contribution to faith-based schools was made by the first confessional cabinet in 1889 . Since then, state payment gradually increased, due to the greater political power of the confessionals that resulted from the expansion of suffrage and of the mobilization of the masses [17]. The School Battle came to an end with the so-called Pacification of 1917, which included two major alterations by constitutional amendment: First, proportional representation and the further expansion of suffrage, and second, full equality of faith-based schools regarding state subsidy. Both measures strengthened the democratic character of the constitutional state, as money no longer hindered free school choice of the citizens, who were also able to vote $[18,19]$.

When it came to the founding of schools, the Constitution of 1917 referred to 'freedom of direction' (vrijheid van richting) without further explanation. In practice, 'direction' was interpreted as a philosophy of life, a denominationally bound ideology or worldview that was visible in society and called for separate organization. In 1933, the schools of the Gereformeerde Gemeenten (Reformed Congregations), one of the main church denominations in the Bible Belt, were recognized as being an independent direction within the Dutch school system. The political organization of the Bible Belt in the SGP was influential in the Raad van State (Council of State) giving them this recognition by Royal Decree [20]. In 1939, the VGS counted 35 connected schools for primary education, and in 1944, the Bible Belt teacher training college De Driestar was launched. Until today, freedom of direction has always been a factor in school founding. In October 2018, however, the Minister for Education introduced a legislative proposal in the Dutch Parliament in which 'direction' is no longer a condition for the founding of a private school. Parliament has not yet made a decision.

After the reorganization of secondary education in 1968, in the 1970s, the Bible Belt community was able to found its own schools, which are currently attended by over 22,000 pupils between ages 12-18. When the education law allowed for it, a school for technical and vocational training for 
16-18-year-olds was also founded (Hoornbeeck College in Amersfoort). This means that various pupils from the Bible Belt can attend exclusively orthodox Reformed schools throughout their entire school career, which has understandably led some people to doubt the ability of these pupils to dialogue with liberal society. However, the Reformed schools for secondary education were not immediately recognized as belonging to an independent direction, a clearly distinguishable sub-denomination within Protestantism (as had been the case with the schools for primary education since 1933). After some legal maneuvering, the Council of State delivered a verdict in a Royal Decree on 8 February 1979 , in which these schools also received the label of independent, 'Reformed' direction. While in 1933, the separate organization and unique spiritual profile of one of the churches, the Gereformeerde Gemeenten, was mainly responsible for the Royal Decree, in 1979, it was not a church but the Bible Belt community as such that was the reason for recognition. In planned procedures for secondary schools, the Department henceforth took into consideration the votes of the Reformed Political Party in certain regions. The decision of 1979 refers to the "conscientious objections" of the Bible Belt community against secondary education at other than strong religious schools, citing the European Convention on Human Rights, "in which [it] is recorded that the State shall respect the right of parents to ensure such education and teaching [is] in conformity with their own religious and philosophical convictions" (ECHR article 2 first protocol) [21]. In current discussions on the strong religious schools, however, the ECHR hardly plays any role.

The Pacification of 1917, we can conclude, stimulated the founding and flourishing of various faith-based schools, which included the strong religious schools of the Bible Belt community. However, the space offered by the state also had its price. The limitations of the Dutch freedom of education have been clearly visible since the 1990s, especially since, in 1994, the General Act on Equal Treatment was accepted in the Dutch parliament, underlining the principle of nondiscrimination. The Act caused a rift between Bible Belt and liberal society and resulted in some court cases about the equal treatment of women and homosexuals in the semipublic sphere of the Reformed Political Party and the strong schools at the Bible Belt $[22,23]$. These court cases make clear that equal treatment leads to diminished freedoms for Christians: i.e., an orthodox Reformed interpretation of the admission of pupils and the recruitment of staff members, in which strong religious schools are asked for consistency in policy. This is, however, not a specific Dutch phenomenon, as all Western European faith-based schools to a greater or lesser extent have been confronted with similar problems when it comes to admission and recruitment ([16], p. 159; cf. [24,25]).

The figure of the homosexual teacher became exemplary of these debates, and due to the persistent discussion about the possible dismissal from a strong religious school, it is considered the locus classicus of equal treatment legislation [25] (p. 43). Choosing to attend a church outside the Bible Belt could also lead to a notification of dismissal for personnel at strong religious schools. And yet, however these schools outline their own policy today, the limits of nondiscrimination are strictly controlled by the court, parliament, and the media. The Bible Belt community experiences the equal treatment legislation as a direct attack on their moral values $[22,23,26]$, and although there have been only a few legal cases about the admission of pupils or the recruitment of teachers in the context of equal treatment legislation, the public perception of strong religion and the experience of limited freedom of movement of Bible Belt schools make it clear that this community feels that they have become 'strangers' in its own country. Because this was caused by decreasing tolerance of the government for religious minorities in favor of the individual's right to equality and nondiscrimination, the plurality of the Dutch school system is under pressure [25,27]. Based on their reconstruction in hindsight, Maussen and Vermeulen [24] interpreted this development as a shift in the conceptualization of religious freedom in relation to liberal equality, which may destabilize substantial collective freedoms for conservative religious groups. In their opinion, this is a break with the Dutch tradition of tolerance towards all kinds of minorities (cf. [28], p. 873).

A good example of how strong religious schools are often treated with suspicion by both policy makers and politicians is a recent case about the funding of an Islamic school. In 2016, state secretary 
of education Sander Dekker announced that he was unwilling to appropriate governmental funds for the founding of a new Islamic school for secondary education in Amsterdam because, in his opinion, it was not sufficiently clear if and how the school would be able to meet the national requirements on citizenship education. The discussions that followed finally ended in the judgment of the Council of State that there are no legal arguments not to support the school financially and that the government is therefore obliged to fund the school [29]. Other questions were also raised regarding strong Christian schools, amongst which the orthodox Reformed schools are included. We quote from a commentary of the editor-in-chief of Trouw, a Dutch national newspaper, responding to the decision of state secretary Dekker not to fund the Islamic school:

What about citizenship education at orthodox Protestant schools that adhere to creationism and fight evolution theory? Homosexuals are not allowed to marry and they also cannot teach at those schools. Of course these opinions are not as state undermining opinions as those of the former Islamic board member, but if freedom of education is the constitutional starting point, then we accept that groups can appeal to that, however disagreeable their opinions might be. The greatest problem is that groups could [ ... ] use democratic rights to strive for undemocratic ends. This possibility leads to tensions, to put it mildly [30].

In our opinion, the editor-in-chief gets to the heart of the matter. The real questions involve dealing with divergent views in a liberal democratic society [31]. This theme is also the background of the main question for this article on the existence of and justification for strong religious schools in secular societies. To contextualize this question and focus on orthodox Reformed schools in the Netherlands, we have taken a historical perspective in order to better understand why these schools are founded and how they are justified within Dutch society. In the remainder of this article, we add some philosophical insights. It is not our aim to summarize or evaluate all existing (academic) literature on faith schools and liberal societies. We highlight some important philosophical notions and relate them to orthodox Reformed schools in the Netherlands. We recommend the 2018 special issue of Theory and Research in Education on 'Faith Schools and Civic Virtue' to readers who want to learn more about current views of philosophers of education on faith schools in liberal societies. We begin with autonomy, as to many contemporary liberal philosophers, this is one of the key goals of education.

\section{Autonomy}

An important question for many liberal thinkers is whether orthodox Christian schools are willing and able to teach their pupils the fundamental rights and rules central to a liberal democratic society [32]. What if "the values of one's own convictions are at odds with liberal values and fundamental rights?" Tensions may arise, for example, over the value of 'equality'. What if, on the basis of one's convictions, it is taught that women are subordinate to men, even though equality of every individual is an important basic value in our society? From this description, it is clear that at least some of the values held by orthodox Reformed Christians are at odds with the values and fundamental rights of a liberal society.

Most liberal philosophers prize an autonomous lifestyle (i.e., to live life free of all constraints) because only then, in their opinion, can liberal values be instilled in children. Callan [33] (p. 118), for example, stated that "autonomy enables us to choose intrinsically good lives: autonomy confers that ability without creating bias against any particular ways of life that might have intrinsic value". Merry [5] (p. 165) agreed, and noted that "being or becoming autonomous means being capable of reflecting upon different points of view and arriving at a reasonable and considered opinion about those things one has reason to value and is able to pursue". However, with Merry, we also believe that there are a number of difficulties with the ideal of autonomy, which was also questioned by De Wolff [32] in her article on strong religious schools in the Netherlands (see, for instance, [5], pp. 174-175 for an enumeration of a few of these difficulties and references to authors who elaborate on them). According to De Wolff, autonomy has become overemphasized, to the point that children 
are no longer taught any specific vision of life. She makes clear that "a lack of roots", meaning that one's identity is not based on family traditions (including religious aspects), can ultimately lead to fundamentalism: "Extreme-fundamentalistic young people no longer confine their identity to the tradition of their parents, but neither can they confine their identity to the offerings of the secularized society that surrounds them" [32] (pp. 163-164).

In this regard, it is interesting to note that fourteen-year-old students at Bradford Christian School expressed in a focus group "that it [Bradford, JE-GBT] offered them more freedom than schools where comprehensively liberal and secular values formed an orthodoxy that they did not feel able to challenge" [1] (p. 185). Students indicated that at their previous public schools, they "felt unable to challenge a secular orthodoxy and believed they were denied a voice because comprehensively liberal beliefs were presented as incontrovertible facts" [1] (pp. 185-186). Empirical findings such as these demonstrate the importance of looking beyond first impressions or prejudices in order to take into account what is really happening in schools [34]. In practice, young people could have more room to develop their own views at strong religious schools than at public schools, where less discussion about beliefs and values is possible.

MacMullen, amongst others, offered another interesting perspective on the role of autonomy development [10,35]. MacMullen argued that if the goal is the development of autonomy, it is better if a 'provisional identity' within a particular primary culture is nurtured in the early years of life. This primary culture, he claims, can serve as a basis for further autonomy development. In short, then, MacMullen believed that especially in the early years (primary school), a close connection between home and school life is beneficial. The provisional set of values and norms, which is shared by both home and school, serves as a starting point for the developing child's own life journey. In this sense, MacMullen's argument underlines the value of Reformed schools for children who grow up in the Bible Belt culture. If students are stigmatized by their secular compatriots exclusively for being part of the Bible Belt culture, it is difficult for these young people to develop a coherent 'provisional identity' within the context of secular education; this stigmatization could be a reason for as well as a result of separate schooling. Additionally, Merry [5] (p. 167) made it clear that to be stigmatized is to be harmed. "Stigmas devalue the stigmatized, and this devaluation is often internalized by the stigmatized themselves." Merry referred to Fricker (2007), who called the result of this stigmatization 'epistemic injustice': "Epistemic injustice occurs when persons lose knowledge, that is, when their ability to know things with confidence is weakened, given how their experiences-but also the manner in which they try to convey these experiences-are not taken seriously by others" [5] (p. 167). We do not have empirical research on the extent to which young people who grow up in the Bible Belt culture feel stigmatized, but there is evidence that points in that direction: Pupils of an orthodox Reformed school for secondary education in the Netherlands expressed that they, to a greater or lesser extent, 'feel different' and are sometimes treated as if they come from another planet [36]. Unfortunately, primary school pupils were not included in this study. For primary school children from a minority group, it is even more important to have their 'own' schools. MacMullen even went so far as to say that his argument (on the importance of a close fit between home and school contexts for autonomy development) only holds for primary education. Autonomous thinking requires the ability to assess different perspectives and reason outside one's own frame of mind. This ability (which is called 'formal deductive reasoning' by developmental psychologist Piaget [37]) is unlikely to be (initially) developed before the age of eleven or twelve. MacMullen, however, stressed that the foundations for children's future autonomy should be laid already in elementary school. He, thus, formulated a few "hallmarks of acceptable pedagogy in a religious elementary school":

In particular, teachers should exercise rational authority by structuring most justifications as reasoned inferences from explicit principles and values, asking and encouraging questions that invite rational analysis and interpretation rather than recitation of dogma, and highlighting hard cases within the religious doctrine where reasonable disagreement exists even among the faithful [35] (p. 613). 
All in all, MacMullen has a much more positive view on religious (primary) schools than many others in our liberal, secular society. Yet, he also does not hesitate to acknowledge possible risks that might impede the future autonomy development of children. The challenges for strong religious schools can be further illustrated with the help of the work of the American philosopher Kenneth Strike [9], who elaborated on the role of comprehensive life conceptions in a plural, liberal democracy. We go further into this in the next section.

\section{Comprehensive Life Conceptions and Public Morality}

An important difference between Strike and other liberal thinkers such as Rawls, Gutman, and Callan is his understanding of the role of comprehensive doctrines and conceptions of the good life. Just like De Wolff, Strike maintained that some authors attach too much value to autonomy at the cost of conceptions of the good life [38]. Strike believes that there should be a dialogical relation between comprehensive life conceptions (as 'primary moral languages') and more basic public morality ('public language') and emphasized that 'the public language' or 'public morality' is not separate from the diverse moral traditions in society. Both languages develop, according to Strike, in interaction with each other, in a process of reciprocal adjustment, and are therefore dynamic.

According to Strike, different interpretations of the public language can be developed in a liberal democratic society, each being congruent with one of the different primary moral languages. De Wolff agreed and concluded that when considering the dynamics of public morality, it is important to allow comprehensive life conceptions into the public debate on the arrangement of our society. In education, children need to learn dialogical competences. Strike distinguished three elements: Children need to achieve competencies in a primary moral language and in the public moral languag, and they need to learn how to have a hermeneutical or critical dialogue between different primary languages [32] (p. 66). In order to be a good citizen in the present liberal democracy, then, it is of foremost importance that children become cognizant of their own life conceptions. They must learn what these conceptions mean for their lives and how they can talk about them with others who share the same life conceptions. Secondly, children must also become acquainted with public morality (which, according to Strike, is inseparable from the primary moral languages) and learn to recognize its importance. Children should also learn how they perceive public morality and how it can reinforce their own perspectives. In other words, children should be able to practice a 'critical dialogue' between different life conceptions. This critical or hermeneutical dialogue serves three aims. In the first place, children learn to understand how others think about their way of life. Secondly, they learn 'reciprocity', the ability to put themselves in other people's shoes. And thirdly, practicing a critical dialogue teaches children how to deal with critics of their own primary moral language and to value their own primary moral language in the proper way. This includes the ability to listen to critics and to (learn to) be open to alternative perspectives. It is, thus, also about being brave enough to criticize one's own perspective [39].

Strong religious schools, by definition, seek to affirm and reinforce the identity of their community (McDonough), and their purpose also includes making pupils aware of their own life conception. Bearing in mind the importance of having a 'provisional identity', we argue that Strike's first mentioned competence is addressed principally at strong religious schools. The challenges for strong religious schools mainly relate to the second and third competences, those dealing with the dialogue about public morality and the dialogue between different life conceptions. As De Wolff noted: "For orthodox Christian schools it is a challenge to teach children that a religious outlook on life always presumes faith; values related to that faith therefore cannot be easily dictated to others. It is typical for a believer to stick to certain values deliberately, because he believes that he is asked or forced to do so out of respect for a higher authority. But that belief cannot be imposed directly on others" ([32] (p. 167) translation GBT). Here, we would like to explicitly stress the challenge of (learning to) have a critical dialogue. Learning to take a critical perspective on one's own tradition and to leave open the possibility of taking another perspective is not evident to orthodox believers. We argue, however, that this ability 
is indeed necessary in order to have a genuine and fair dialogue with people who hold different life conceptions. In our view, this means that there should always be the possibility to change one's life conception. (Religious) traditions change over time in relation to changes in mainstream society. This is the only way to fully realize the dialogical relation between comprehensive life conceptions and basic public morality. The Bible Belt culture has shown potential in this area in its changing views on male-female relationships in public duties, for example [23].

\section{Conclusions and Discussion}

Our article aimed to answer the question: How can the founding and existence of orthodox Reformed schools in a liberal, secular society be explained and justified? We focused on the Dutch context and began by elaborating on the Bible Belt community and its Reformed schools as a particular kind of strong Christian schools. These schools were founded under favorable conditions, in comparison with most other Western European faith-based schools, which have had less space to flourish. The schools successfully justified their existence with a plea for religious freedom. However, we pointed out the transformation of plurality and toleration under the influence of the introduction of equal treatment legislation at the end of the twentieth century. For strong religious schools-Islamic as well as Reformed - this transformation resulted in a widening gap between liberal democracy and its values, because these schools wanted to follow their own policies. Such policies include educating pupils from its religious community alone, a ban on homosexual teachers, and allowing plenty of room for their religious views in the curriculum. These freedoms are under pressure today.

Drawing on the work of both MacMullen and Strike, we elaborated on the educational opportunities and challenges for orthodox Reformed schools in a liberal and secular society. Especially in the case of primary schools, they are justified by their ability to connect education with the home environment of children, thereby contributing to a strong 'provisional identity' that can serve as a firm basis for a child's later development. However, elementary education should also lay the foundation for a child's future autonomy. Thus, children should be encouraged, amongst other things, to ask questions and to learn dialogical competences that enable them to achieve skills in their primary moral (religious) language, in the public moral language, and in the fruitful dialogue between them. This last skill can be especially challenging for orthodox Reformed schools. Therefore, we recommend that teacher training institutes support (future) teachers in strong religious schools by, amongst other things, providing them with examples and stimulating reflection and dialogue amongst teachers themselves.

As adolescents from twelve years and older are expected to have developed the ability to see different perspectives and reason outside their own frame of mind, there are fewer reasons to support orthodox Reformed schools for secondary education. However, as few twelve-year-olds are able to reason in a formally deductive way at a consistently high level, as MacMullen admitted [10], one doubts whether it is useful to make such a sharp distinction between primary and secondary education here. The extent to which young people raised within the Dutch Bible Belt community experience stigmatization could also be a factor; autonomy development is not the only argument that could or should be used to justify the existence of a particular kind of (religious) education.

Given the current public and political debate on orthodox Reformed schools in our liberal society (in relation to the principle of nondiscrimination), we contend that orthodox Reformed schools for secondary education especially need to formulate clear responses to questions about how their continued existence contributes both to the development of their pupils and to society as a whole: What do they want to teach their pupils about living with orthodox beliefs and values in modern society, in which way can this teaching contribute to good citizenship, and, above all, what are their views on living together with various and contrasting (religious) worldviews in the 21st century? As these are important and even existential questions with implications for everyday school practice, we urge strong religious schools to help and stimulate each other in order to deal with them. We also recommend that board members of strong religious schools seek dialogue with nonstrong religious schools and/or 
school advisors with expertise in nonstrong religious schools as well. By contrasting one's views with those from outside one's own (minority) culture, one is stimulated to practice the competences needed in a diverse society and to sharpen and clarify one's own views. Teachers should also be encouraged to practice these competences themselves in order to be good examples for their pupils.

Essentially, the discussed educational challenges and opportunities are valid for all kinds of (strong) religious schools in our liberal, secular society. However, the extent to which schools are willing and able to teach young people all three necessary competences depends on (amongst other things) the position of their (religious) group in society as a whole and their interpretation of their Holy Book(s) and/or tradition. Further (empirical) research could offer useful insights here. Returning to the words of Pike [1], we believe that it is now the best of times for orthodox Reformed schools not only to defend the freedom of those who do not wish to (fully) confirm with the values of the secular mainstream, but also to contribute to broader social cohesion by stimulating their pupils' dialogical competences.

Author Contributions: Conceptualization, all authors; methodology, all authors; software, all authors; validation, all authors; formal analysis, all authors; investigation, all authors; resources, all authors; data curation, all authors; writing — original draft preparation, all authors; writing — review and editing, all authors; visualization, all authors; supervision, all authors; project administration, all authors.

Funding: This research received no external funding.

Conflicts of Interest: The authors declare no conflict of interest.

\section{References}

1. Pike, M. A Tale of Two Schools: Comparing and Contrasting Jacobus Fruytier Scholengemeenschap in the Netherlands and Bradford Christian School in England. J. Beliefs Values 2010, 31, 181-190. [CrossRef]

2. Burtonwood, N. Cultural Diversity, Liberal Pluralism and Schools: Isaiah Berlin and Education; Routledge: Abingdon, UK, 2006.

3. Ofsted. The Annual Report of her Majesty's Chief Inspector of Education, Children's Services and Skills 2016/2017; Open Government Licence; Crown: London, UK, 2017.

4. Adams, R.; Mason, R. Private Faith Schools Are Resisting British Values, Says Ofsted Chief. The Guardian, 13 December 2017; 12.

5. Merry, M.S. Indoctrination, Islamic schools, and the broader scope of harm. Theory Res. Educ. 2018, 16, 162-178. [CrossRef] [PubMed]

6. MacMullen, I. Religious schools, civic education, and public policy: A framework for evaluation and decision. Theory Res. Educ. 2018, 16, 141-161. [CrossRef]

7. McDonough, K. Can the Liberal State Support Cultural Identity Schools? Am. J. Educ. (Chic Ill) 1998, 106, 463-499. [CrossRef]

8. van Lieburg, F.A. (Ed.) Refogeschiedenis in Perspectief: Opstellen over de Bevindelijke Traditie; Groen: Heerenveen, The Netherlands, 2007.

9. Strike, K.A. Liberalism, Communitarism and the Space Between: In Praise of Kindness. J. Moral Educ. 2000, 29, 133-147. [CrossRef]

10. MacMullen, I. Faith in Schools? Autonomy, Citizenship and Religious Education in the Liberal State; Princeton University Press: Princeton, NJ, USA, 2007.

11. Janse, C.S.L. Bewaar het Pand: De Spanning Tussen Assimilatie en Persistentie bij de Emancipatie van de Bevindelijk Gereformeerden; Den Hertog: Houten, The Netherlands, 1985.

12. Janse, C.S.L. De Refozuil Onder Vuur; De Banier: Apeldoorn, The Netherlands, 2015.

13. Schmeets, H. Wie is Religieus, en Wie Niet? Centraal Bureau voor de Statistiek: Den Haag, The Netherlands, 2018.

14. Napel, H.M.T.D. ten. Een Nederlandse Taliban? In De Multiculturele Samenleving en het Recht; van Manen, N.F., Ed.; Paul Scholten Instituut/Ars Aequi Libri: Nijmegen, The Netherlands, 2002; pp. 151-157.

15. Exalto, J. Kerk, school en partij: De SGP als politieke representatie van de bevindelijk gereformeerden. In Mannen van Gods Woord: De Staatkundig Gereformeerde Partij 1918-2018; Vollaard, H., Voerman, G., Eds.; Verloren: Hilversum, The Netherlands, 2018; pp. 47-68. 
16. Glenn, C.L. Educational Freedom and Protestant Schools in Europe. In International Handbook of Protestant Education; Jeynes, W., Robinson, D.W., Eds.; Springer Science+Business Media: Dordrecht, The Netherlands, 2012; pp. 139-161.

17. Naylor, W. School Choice and Religious Liberty in the Netherlands: Reconsidering the Dutch School Struggle and the Influence of Abraham Kuyper in Its Resolution. In International Handbook of Protestant Education; Jeynes, W., Robinson, D.W., Eds.; Springer Science+Business Media: Dordrecht, The Netherlands, 2012; pp. 245-274.

18. de Muynck, A.; Miedema, S.; ter Avest, I. Education and Religion in the Netherlands. In International comparative perspectives on religion and education; Wolhuter, C., De Wet, C., Eds.; SunPress: Bloemfontein, South Africa, 2014; pp. 107-125.

19. Exalto, J. Van Wie is het Kind? Twee Eeuwen Onderwijsvrijheid in Nederland; Balans: Amsterdam, The Netherlands, 2017.

20. Koninklijk Besluit 15 mei 1933, no. 22. In Administratieve en Rechterlijke Beslissingen BETREFFENDE het Openbaar bestuur in Nederland; Tjeenk Willink: Zwolle, The Netherlands, 1933; pp. 543-545. (In Dutch)

21. Exalto, J. Het reformatorisch onderwijs en de vrijheid van richting, 1920-1980. In De multiculturele refoschool: Het Reformatorisch Onderwijs en de Uitdaging van het Pluralisme; Exalto, J., Ed.; Labarum Academic: Apeldoorn, The Netherlands, 2017; pp. 79-117.

22. Oomen, B. Between Rights Talk and Bible Speak: The Implementation of Equal Treatment Legislation in Orthodox Reformed Communities in the Netherlands. Hum. Rights Q. 2011, 3, 175-200. [CrossRef]

23. Oomen, B.; Rijke, N. The Right to be Different: Homosexuality, Orthodoxy and the Politics of Global Legal Pluralism in Orthodox-Protestant Schools in the Netherlands. J. Law Relig. 2013, 28, 361-400. [CrossRef]

24. Maussen, M.; Vermeulen, F. Liberal Equality and Toleration for Conservative Religious Minorities: Decreasing Opportunities for Religious Schools in the Netherlands? Comp. Educ. 2015, 51, 87-104. [CrossRef]

25. Vermeulen, B.P. Regulating School Choice to Promote Civic Values: Constitutional and Political Issues in the Netherlands. In Educating Citizens: International Perspectives on Civic Values and School Choice; Wolf, P., Macedo, S., Eds.; Brookings Institution Press: Washington, DC, USA, 2004; pp. 31-66.

26. Rijke, N. Strijd om en binnen de refoschool: Over culturele verschillen, mensenrechten en het benoemingsbeleid. In De Multiculturele Refoschool: Het Reformatorisch Onderwijs en de Uitdaging van het Pluralisme; Exalto, J., Ed.; Labarum Academic: Apeldoorn, The Netherlands, 2017; pp. 119-146.

27. Ter Avest, K.H.; Rietveld-van Wingerden, M. Half a century of Islamic education in Dutch schools. BJRE 2017, 39, 293-302. [CrossRef]

28. Merry, M.S.; Driessen, G. On the Right Track? Islamic Schools in the Netherlands after an Era of Turmoil. Race. Ethn. Educ. 2016, 19, 856-879. [CrossRef]

29. Vissers, P. Dekker moet islamitisch onderwijs in Amsterdam financieren. Trouw, 27 July 2017; 17.

30. van der Laan, C. Commentaar: Dekker gaat onzekere weg op. Trouw, 1 June 2016; 21.

31. Miedema, S.; Bertram-Troost, G.D. Democratic Citizenship and Religious Education: Challenges and Perspectives for Schools in the Netherlands. BJRE 2008, 30, 123-132. [CrossRef]

32. de Wolff, A. Religie, fundamentalisme en burgerschap. In Levensbeschouwelijk Leren Samenleven: Opvoeding, Identiteit $\mathcal{E}$ Ontmoeting; Miedema, S., Bertram-Troost, G.D., Eds.; Meinema: Zoetermeer, The Netherlands, 2006; pp. 155-170. (In Dutch)

33. Callan, E. Autonomy, child-rearing and good lives. In The Moral and Political Status of Children; Archard, D., Maclead, C., Eds.; Oxford University Press: Oxford, UK, 2002; pp. 118-141.

34. Bertram-Troost, G.D. Investigating the Impact of Religious Diversity in Schools for Secondary Education: A Challenging but Necessary Exercise. BJRE 2011, 33, 271-283. [CrossRef]

35. MacMullen, I. Education for Autonomy: The Role of Religious Elementary Schools. J. Philos. Educ. 2004, 38, 601-615. [CrossRef]

36. Baars-Blom, J.M. De Onschuld Voorbij: over Reformatorische Cultuur en Wereldbestormende Meisjes; Kok: Kampen, The Netherlands, 2006.

37. Piaget, J. Judgement and Reasoning in the Child; Warden, M., Translator; Harcourt, Brace \& Co.: New York, NY, USA, 1976. 
38. van Leest-Borst, A. Fundamentalistische Opvoeding Vanuit Liberaal-Democratisch Perspectief: Grenzen van Onderwijsvrijheid. Ph.D. Thesis, Department of Psychology and Education, Vrije Universiteit, Amsterdam, The Netherlands, 2005.

39. Bertram-Troost, G.D. Refoscholen op de balk: Balanceren tussen eigenheid en openheid. In De Multiculturele Refoschool: Het Reformatorisch Onderwijs en de Uitdaging van het Pluralisme; Exalto, J., Ed.; Labarum Academic: Apeldoorn, The Netherlands, 2017; pp. 23-56. 